Özdemir Bişkin, S. \& Sop, A. (2021). Karakter Güçleri Envanteri Erken Çocukluk Formu'nun Türkçeye uyarlanması: Geçerlik ve güvenirlik çalışması. Bolu Abant İzzet Baysal Üniversitesi Eğitim Fakültesi Dergisi, 21(1), 177-193. https://dx.doi.org/10.17240/aibuefd.2021.21.60703-654580

Makalenin Türü / Article Type Geliş Tarihi / Date Received Kabul Tarihi / Date Accepted Yayın Tarihi / Date Published
: Araștırma Makalesi / Research Article

: 03.12.2019

$: 22.02 .2021$

$: 15.03 .2021$

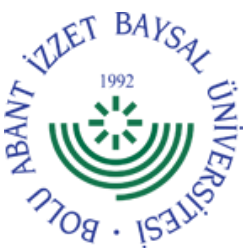

\title{
KARAKTER GÜÇLERİ ENVANTERİ ERKEN ÇOCUKLUK FORMU'NUN TÜRKÇEYE UYARLANMASI: GEÇERLIKK VE GÜVENİRLİK ÇALIŞMASI
}

\author{
Serap ÖZDEMIR BIŞKIN ${ }^{1}$, Aylin SOP²
}

öz

Bu araştırmanın amacı Shoshani (2018) tarafından geliştirilen Karakter Güçleri Envanteri Erken Çocukluk Formu'nun Türkçeye uyarlanarak geçerlik ve güvenirlik çalışmasının yapılmasıdır. Bu amaç doğrultusunda, okul öncesi eğitim kurumlarına devam eden 4-6 yaş çocukların ebeveynlerinden 311 araştırma verisi elde edilmiştir. Envanterin orijinal formu 96 madde, 24 alt faktör ve 4 temel boyuttan oluşmaktadır. Uyarlanan envanterden elde edilen veriler ile orijinal formun yapısına uygunluğunu incelemek için doğrulayıcı faktör analizi (DFA) yapılmış, DFA sonucunda ölçeğin orijinal formunun korunduğu görülmüştür. Envanterin güvenirlik analizleri için iç tutarlık katsayıları ve düzeltilmiş madde toplam korelasyonları hesaplanmıştır. Elde edilen Cronbach alfa katsayıları kişilerarası güçler boyutu için 0.91; entelektüel güçler boyutu için 0.86; ölçülülük boyutu için 0.88 ve aşkınlık boyutu için 0.89 olarak hesaplanmıştır. Yapılan analizler neticesinde Karakter Güçleri Envanteri Erken Çocukluk Formu'nun Türk kültüründe geçerli ve güvenilir bir ölçme aracı olduğu belirlenmiştir.

Anahtar Kelimeler: Karakter güçleri, erken çocukluk dönemi, ölçek uyarlama, geçerlik, güvenilirlik

\section{TURKISH ADAPTATION OF THE CHARACTER STRENGTHS INVENTORY EARLY CHILDHOOD FORM: A VALIDITY AND RELIABILITY STUDY}

\begin{abstract}
The purpose of the current study is to adapt the Character Strengths Inventory for Early Childhood developed by Shoshani (2018) to Turkish by conducting its validity and reliability studies. To this end, a total of 311 research data were collected from the parents of 4-6 year olds attending pre-school institutions. The original form of the inventory consists of 96 items, 24 subfactors and 4 main dimensions. Confirmatory factor analysis (CFA) was run to investigate the compliance of the data collected from the adapted inventory with the construct of the original form and as a result of this CFA, it was found that the construct of the original scale was retained. For the reliability analyses of the scale, internal consistency coefficients and item total correlations were calculated. The calculated Cronbach alpha coefficients are as follows: 0.91 for the Interpersonal Strengths dimension; 0.86 for the Intellectual Strengths dimension; 0.88 for the Temperance dimension and 0.89 for the Transcendence dimension. As a result of the analyses, it was concluded that the Character Strengths Inventory for Early Childhood can be used as a valid and reliable measurement tool in the Turkish culture.
\end{abstract}

Keywords: Character strengths, early childhood, adaptation, validity, reliability

\footnotetext{
${ }^{1}$ Burdur Mehmet Akif Ersoy Üniversitesi, Eğitim Fakültesi, sozdemir@mehmetakif.edu.tr,@ https://orcid.org/0000-0002-1592-6952
} ${ }^{2}$ Burdur Mehmet Akif Ersoy Üniversitesi, Eğitim Fakültesi, adursun@mehmetakif.edu.tr, (1) https://orcid.org/0000-0003-4962-0326 


\section{GíRiş}

Karakter kavramı yıllar boyunca ahlak felsefecilerinin ve din düşünürlerinin insanlarda değer verdiği temel özelliklerden biri olmuştur (Park \& Peterson, 2009). Psikoloji alanında ise karakter özellikleri araştırmaları birkaç istisnai araştırma dışında yakın tarihe kadar ihmal edilen bir alandır (Park, 2004). Bu nedenle çağlar boyunca, karakterin kavramsallaştırılması ve geliştirilmesi, filozofların ve ilahiyatçıların temel çalışma alanları arasında yerini almışken ruh sağlığı uzmanlarının ve eğitimcilerin bu alanda yaptıkları çalışmalar sınırlı düzeyde kalmıştır. Gelişim psikologlarından olan Piaget ve Kohlberg, ahlaki gelişimi tanımlamak için teorik çerçeveler sağlasa da, çalışmaları temel olarak ahlaki biliş üzerinde durmakta, ahlaki davranışa odaklanmamaktadır (Park, 2004). Ancak son yirmi yıldır çağdaş pozitif psikoloji hareketinin gelişimi ile beraber bireylerin güçlü yönlerine odaklanma, iyi yaşamın desteklenmesinde önemli bir rol oynayan karakter özelliklerinin psikoloji alanında da çalş̧ılmasını hızlandırmıştır (Seligman, 2002). Seligman ve Csikszentmihalyi (2000) güçler ve erdemlerin önemine yönelik ilk araştırmaları yürütmüşler ve pozitif bireysel özelliklerin geliştirilmesinin eğitimciler ve ruh sağllğı uzmanlarına problemleri önlemede yol gösterici olabileceğini öngörmüşlerdir. Bu bağlamda daha güncel araştırmalarda karakter güçlerinin iyileştirilmesinin iyi oluş (Martínez-Martí \& Ruch, 2014; Proctor vd., 2011; Shoshani, 2018; Shoshani \& Slone, 2013), yaşam doyumu (Gillham vd., 2011; Park vd., 2004; Proctor vd., 2011) ve yaşamda anlam (Seligman vd., 2006) gibi bireyin pozitif gelişimini destekleyen diğer özelliklerin gelişimine olumlu yönde etki ettiği de ortaya koyulmuştur.

Toplumsal yaşamda dürüstlük, adalet, nezaket veya cesaret gibi güçlü yönler herkesçe kabul edilen olumlu özelliklerdir. Bu özellikler eğitimcilerin öğrencilerinde, ebeveynlerin çocuklarında, eşlerin birbirlerinde, kısaca her bireyin diğerinde aradığı temel özelliklerdir (Park \& Peterson, 2006a). Pozitif psikoloji hareketi ile güçlü karakter özelliklerine verilen önem 'iyi karaktere' sahip bir gençlik yetiştirebilmek için iyi karakteri belirleyen özelliklerin tanımlanmasını gerekli kılmıştır. Bu ihtiyaç doğrultusunda Peterson ve Seligman'ın öncülüğünde elliden fazla akademisyen ve klinisyen üç yıllık bir projede bir araya gelip karakter ve erdemlerin tarihsel gelişimi, popüler literatür ve medyayı inceleyerek güçlü bir beyin firtınası ile dünyanın farklı kültürlerinde yaygın geçerliği olan altı erdem ve 24 karakter gücü belirlemişlerdir. Araştırılan kültürler arasında Çin'de yaygın olan Konfüçyanizm ve Taoizm, Hindistan Yarımadası'ndaki Budizm ve Hinduizm; Hristiyanlık ve İslamiyet yer almaktadır. Bu kapsamlı araştırma sonucunda Karakter Gücü ve Erdemler Sınıflandırması (VIA sınıflandırması) el kitabının yayınlanması ile karakter güçleri daha somut hale gelmiştir ve karakter güçlerine ilişkin ortak bir dil oluşturulmuştur (Peterson \& Seligman, 2004).

Peterson ve Seligman (2004) iyi karakterli olmayı tek bir özellikten ziyade iyi geliştirilmiş güçlü yönler kümesi olarak ifade etmektedir. Karakter güçlerini daha iyi anlayabilmek ve ayırt edebilmek için karakter güçlerinin erdem, yetenek, beceri ve değer gibi bireye ait diğer güçlü yönlerle olan benzerlik ve farklılıklarının ortaya koyulması anlamlıdır. Karakter güçleri ve erdemler arasındaki ilişkiye bakıldığında karakter güçlerinin erdemleri tanımlayan ve belirleyen psikolojik süreçler olduğu görülür. Diğer bir ifadeyle karakter güçleri erdemlere ulaşmayı sağlayan özgün yollardır. Örneğin bilgelik erdemine ulaşmanın yolu öğrenme sevgisi, merak ve çok yönlü bakış açısı gibi güçlere sahip olmaktan geçer (Kabakçı, 2016). Diğer kişisel güçlü yönlerden yetenek ve beceriler ile karakter güçleri arasındaki fark incelendiğinde yetenek ve becerilerin karakter güçlerine göre daha kalitsal özellikler gösterdiği görülmektedir Aynı zamanda yetenek ve beceriler karakter güçlerine göre daha somut sonuçlarla (şöhret, zenginlik vb.) ilişkilendirilir. Karakter güçleri ise somut sonuçlardan ziyade ahlaki olarak arzu edilene ulaşmayı hedefler (Peterson, 2006). Karakter güçleri ile karıştırılabilen bir başka kavram olan değerler ile karakter güçleri arasındaki fark ise şu şekilde belirtilebilir: Değerler büyük ölçüde dini, kültürel ve politik bir bağlamda ele alınırken (Peterson, 2006), karakter güçleri daha çok bireyi tanımlayıcı özelliklerdir.

Karakter Gücü ve Erdemler Sinıflandırması'na (Peterson \& Seligman, 2004) göre temel erdemler "insaniyet, adil olma, ölçülü olma, aşkınlık, bilgelik ve cesaret" olmak üzere altı farklı kategoride sınıflandırılmıştır. Bu erdemleri açıklayan 24 karakter gücü; sosyal zekâ, sevme ve sevilme, nezaket, hakkaniyet, takım çalışması, bakış açısı, liderlik, cesur olma, öğrenme hevesi, merak, güzellikleri takdir etme, yaratıcllık, ihtiyatlllık (tedbirli olma), öz düzenleme, affetme, açık fikirlilik, alçakgönüllüllük, kararlılık, coşkulu olma, minnettarlık, maneviyat, umut, mizah, dürüstlük olarak sınıflandırılmıştır. Tablo 1'de karakter güçleri ve erdemler sınıflaması (Peterson \& Seligman, 2004) ayrıntılı bir şekilde özetlenmiştir.

\section{Tablo 1.}

VIA Karakter Güçleri ve Erdemler Sinıflandırması

\begin{tabular}{lll}
\hline Erdemler & Karakter Güçleri & Açıklamalar \\
\hline \multirow{2}{*}{ İnsaniyet } & Sosyal Zekâ & Kendisi ve başkalarının dürtü ve duygularının farkında olma \\
& Sevme ve Sevilme & Başkaları ile yakın ilişkilere değer verme \\
& Nezaketli olma & Başkalarına karşı nazik olma, şefkatli olma ve başkaları için iyilik yapma \\
\hline \multirow{2}{*}{ Adil Olma } & Adalet (Hakkaniyet) & Adalet kavramlarına göre bütün insanlara aynı davranmak \\
& Takım çalışması & Bir grubun veya ekibin üyesi olarak uyumlu çalışabilmek \\
& Liderlik & Grup etkinlikleri düzenlemek ve bunları gerçekleştirmek \\
\hline
\end{tabular}




\begin{tabular}{|c|c|c|}
\hline $\begin{array}{l}\text { Tablo 1. (deva } \\
\text { VIA Karakter }\end{array}$ & Sü̈çleri ve Erdemler Sınıflc & lirmast \\
\hline Erdemler & Karakter Güçleri & Açıklamalar \\
\hline & Affetme & Yanlış yapanları affetmek \\
\hline Ölcülülïk & Alçakgönüllülük & Başarıları ile övünmemek \\
\hline Olçưlülük & İhtiyatll11k (tedbirli olma) & Pişman olabileceği şeyleri söylememek veya yapmamak \\
\hline & Öz düzenleme & Duygu ve davranışları düzenlemek \\
\hline & Minnettarlık & Gerçekleşen iyi şeylerden haberdar olmak ve minnettar olmak \\
\hline & Maneviyat & Yaşamın yüksek amacı ve anlamı hakkında tutarlı inançlara sahip olmak \\
\hline & Umut & En iyisini beklemek ve bunu başarmak için çalışmak \\
\hline Aşkınlık & Mizah & Gülmeyi ve şaka yapmayı sevmek; başkalarını gülümsetmek \\
\hline & Güzellikleri takdir etme & $\begin{array}{l}\text { Yaşamın tüm alanlarında güzelliğin, mükemmelliğin ve / veya performansın } \\
\text { farkına varılması ve takdir edilmesi }\end{array}$ \\
\hline & Bakış açısı & $\begin{array}{l}\text { Farklı açılardan düşünmek ve araştırmak. Başkalarına akıllıca danışmanlık } \\
\text { sunabilmek }\end{array}$ \\
\hline & Öğrenme hevesi & Yeni becerilere, konulara ve bilgi organlarına hakim olmak \\
\hline Bilge/Bilgelik & Açık fikirlilik & Bir şeyleri geniş düşünmek ve her yönden incelemek \\
\hline & Merak & $\begin{array}{l}\text { Yenilik arayışı ve yeni deneyimlere açık olmak, devam eden tüm tecrübelere ilgi } \\
\text { göstermek }\end{array}$ \\
\hline & Yaraticilık & İşleri yapmanın yeni ve üretken yollarını düşünme \\
\hline & Cesur olma & Tehdit, meydan okuma, zorluk veya acıdan kaçınmamak \\
\hline Cecar & Kararlılık & Başlanan işi bitirmek \\
\hline Cesaret & Coşkulu olma & Canlılık, hayatta hissetmek ve her türlü faaliyet için coşku göstermek \\
\hline & Dürüstlük & Gerçeği söylemek ve kendini gerçek bir şekilde sunmak \\
\hline
\end{tabular}

Peterson ve Seligman (2004) tarafından önerilen altı erdem ve yirmi dört karakter gücü uzmanların araştırmaları sonucunda "teorik" olarak türetilmiştir. Öte yandan erdemler ve karakter güçleri ile ilgili yapılan araştırmalar 24 karakter gücü için teorik olarak türetilen bu erdemlerden daha farklı erdem sınıflandırmaları ortaya koymuşlardır. Tablo 2'de farklı araştırmalara göre erdem sınıflandırmaları özetlenmiştir.

\section{Tablo 2.}

Farklı Araştırmalara Göre Erdemlerin Sınıflandırllması

\begin{tabular}{ll}
\hline Araştırmalar & Erdem Sımıflamaları \\
\hline Peterson vd. (2008) & Kişilerarası, Dayanıklılı, Bilişsel, Aşkınlık, Ölçülülük \\
Macdonald vd. (2008) & Pozitiflik, Entelektüel, Dürüstlük, Hassaslık \\
Brdar \& Kashdan (2010) & Kişilerarası, Dayanıklılı, Canlılık, Ihtiyatlı Olma \\
Ruch vd. (2010) & Duygusal, Kişilerarası, Kendini Kisıtlama, Entelektüel, Teolojik \\
Singh \& Choubisa (2010) & Toplumsal, Kendine Güven, Kişileraras, Entelektüel, Teolojik \\
Shryack vd. (2010) & Kendine Güven, Sosyallik, Dürüstlük \\
Shoshani \& Aviv (2012) & Kişilerarası, Entelektüel, Ölçülülük, Aşkınlık \\
Littman-Ovadia \& Lavy (2012) & Kendini Kısıtlama, Entelektüel, Duygusal, Teolojik \\
McGrath (2014) & Yardımseverlik, Merak ve Öz-kontrol \\
\hline Kaynak: Bu tablo McGrath (2014) ve Shoshani ve Aviv’in (2012) araștırmalarından olussturulmustur.
\end{tabular}

Tablo 2 incelendiğinde, yirmi dört karakter gücünün; üç (Littman-Ovadia \& Lavy 2012; McGrath, 2014; Peterson vd., 2008; Shryack vd., 2010); dört (Brdar \& Kashdan, 2010; Macdonald vd., 2008; Shoshani \& Aviv, 2012) ve en fazla beş boyutta (Ruch vd., 2010; Singh \& Choubisa, 2010) gruplandığı görülmektedir.

Karakter güçlerini fark etmek ve bunları olumlu yönde harekete geçirmek bireyin yaşamında birtakım avantajlar sağlamaktadır. Örneğin karakterin güçlü yönleri, kişinin zorluklarla ve stresle başa çıkma becerisini kuvvetlendirirken aynı zamanda sosyal ve akademik yönden gelişimini de desteklemektedir. Bu bağlamda yapılan araştırmalar karakter güçlerinin depresyon (Gillham vd., 2011; Kim vd., 2018; Tehranchi vd., 2018) ve intihar davranış1 (Corral-Verdugo vd., 2014) ile negatif yönde ilişkili olduğunu göstermektedir. Kim vd. (2018) yaptıkları araştırmaya göre yaratıcılık ve takım çalışması karakter güçleri, depresyonu önlemede, nezaketli ve adaletli olma karakter güçleri ise intiharı önlemede önemli koruyucu faktörlerdir. Benzer şekilde Gillham vd. (2011) da takım çalışması, affetme ve nezaketli olma güçlerinin ergenlerde depresyon belirtileri ile negatif yönde ilişkili olduğunu ortaya koymuşlardır. Araştırmalarda da görüldüğü üzere karakter güçleri ile duygusal problemler arasında negatif ilişkiler söz konusu iken karakter güçleri ile bireylerin iyi oluş düzeyi (Martínez-Martí \& Ruch, 2014; Proctor vd., 2011; Shoshani, 2018; Shoshani \& Slone, 2013) ve yaşam doyumu (Gillham vd., 2011; Park vd., 2004; Proctor vd., 2011) arasında pozitif yönde ilişkiler bulunmuştur. Bunların yanı sıra Lounsbury vd. (2009) araştırmalarında kararlılık, öğrenme hevesi, adalet ve nezaket gibi karakter güçlerinin akademik başarıyı öngördügüunü vurgulamaktadırlar. Shoshani ve Slone'ın (2013) yaptıkları araştırmaya göre de entelektüel ve ölçülü olma karakter güçleri okul başarısını artırırken, kişilerarası güçler, okuldaki sosyal işlevsellikle ilişki göstermektedir.

Yukarıda bahsedildiği gibi karakter güçleri farklı yaş grupları üzerinde özellikle son 20 yıldır araştırılan konulardandır. Ancak pozitif psikoloji alanında çocukların güçlü yönlerine ilişkin yapılan araştırmalar diğer yaş 
gruplarına göre daha yavaş ilerlemektedir (Baker vd., 2017; Park \& Peterson, 2006b; Rashid vd., 2013; Shoshani \& Slone, 2017). Bu nedenle çocuklarda karakter güçlerinin gelişimine yönelik daha çok araştırmaya ihtiyaç vardır.

\subsection{Erken çocukluk döneminde karakter güçlerinin gelişimi}

Erken çocukluk dönemindeki çocukların başkalarıyla işbirliği halinde çalşsabilme, duygularını ifade edebilme, başkalarının duygu ve davranışlarını anlama, akranlarına destek verme ve şefkat gösterme gibi karaktere özgü özellik ve becerilere sahip olmaları istenir. Bu beceriler sayesinde çocuklar başkalarılyla etkileşime girmeyi, ilişkiler kurmayı ve kendi karakter özelliklerini geliştirmeyi öğrenirler (Beaty, 1999). Tüm çocuklar bu becerileri geliştirme potansiyeline sahipken hem biyolojik hem de çevresel faktörler gelişim sürecine katkıda bulunurlar. $\mathrm{Bu}$ yaşamsal becerilerin eksikliği ise çocukların birbirleri ile etkileşime girme şekillerini, akranları ve başkaları ile ilişki kurma şekillerini etkilemektedir.

Wiley (2000), bir çocuğun bütüncül olarak gelişimini desteklemek için karakter gelişiminin önemini vurgulamaktadır. Erken çocukluk dönemindeki çocukların gelişiminde karakterin gelişimine verilen önem çocukları düşünmeye, değer vermeye ve problem çözmeye yönlendirecektir. Eğitimde çocukların karakter güçlerine verilen önem, çocukların başta kendilerine değer vermelerini ve kendilerini iyi hissetmelerine destek olacaktır. Kendine değer veren bireyler olarak yetişen çocuklar benzer davranışlar gösteren yetişkinler olarak büyüyecektir (Priest, 2007). Bu nedenle özgüvenli ve özsaygısı olan bireyler yetiştirebilmek için çocuklara uygun deneyimler sağlamak bu noktada önemlidir. Oyun ve diğer aktiviteler yoluyla çocuklara sağlanan deneyimler, çocukların becerilerinin gelişmesine, keşfeden ve problem çözebilen çocuklar olmalarına firsatlar sağlayacaktır. Alan yazın araştırmaları incelendiğinde, erken çocukluk döneminde karakterin güçlü yönlerinin belirlenmesi ve geliştirilmesine yönelik çalışmaların eksikliği göze çarpmaktadır. Ancak erken çocukluk dönemindeki çocukların 24 karakter gücünü gösterdiğine yönelik deneysel çalışmalar mevcuttur. Örneğin iki yaşın altındaki çocukların üzücü bir olay karşısında (örneğin, ağlayan bir arkadaşına oyuncak verirken) şefkatle ve empatiyle karşılık verdikleri görülmüştür (Eisenberg \& Fabes, 1992). Ayrıca bebeklerin çok erken yaşlardan itibaren duygusal gelişimlerinde bireysel farklılıklar görülmektedir (Moreno \& Robinson, 2005). Ayrıca Costin ve Jones (1992) çalışmalarında küçük çocukların başkalarına sıkıntı yaratan durumlarını tanımlayabildiklerini ve bu sıkıntılı durumlarını anlayabildiklerini belirtmişlerdir.

Bebeklerin ilk yıllarındaki gelişimlerine bakıldığında sözel ifade yetenekleri geliştikçe adalet ve dürüstlük konularıyla ilgili davranışlar göstermeye başladıkları görülmektedir (Dunn, 1988). Ayrıca araştırmalar, çocuklar arasında takım çalışması ve işbirliğinin yaşamın ilk yıllarında gelişmeye başladığı ve kademeli olarak artmaya devam ettiğini göstermektedir. Özellikle yeni yürümeye başlayan çocukların diğer insanlar ile olan olumlu etkileşimlerini sürdürebilmek için nesneleri değiş-tokuş etme ve paylaşma gibi davranışlar gösterdikleri görülmüştür (Eckerman vd., 1989; Warkenen vd., 2006). Üç yaşa doğru ise çocuklar kendiliğinden minnettar olduklarını gösteren davranışlar sergilemeye başlarlar. Becker ve Smenner (1986) araştırmalarında çocukların \%37'sinin tanımadıkları yetişkinlerden ya da akranlarından hediye aldıklarında minnettar olduklarını gösteren davranışlar sergilediklerini bulmuşlardır. Brownell vd. (2007) ise üç-dört yaşındaki çocukların yapabilecekleri/yapmaları gereken ile yapamayacakları/yapmamaları gereken davranışlar konusunda doğru karar vermeye başladıklarını vurgulamışlardır.

Küçük çocukların karakter güçlerini değerlendirmek ve küçük çocuklar için yeni bir karakter sınıflandırması yapmak için ilk kez Park ve Peterson (2006b) bir çalışma yürütmüşlerdir. Bu çalışma küçük çocukların (on yaş altı) çok boyutlu olarak karakterlerini araştıran ilk çalışma olması nedeniyle önemli görülmektedir. Araştırmanın amacı 3-9 yaş arasındaki çocukların karakter güçlerini belirlemek ve bu güçlerin mutluluk ile olan ilişkisini araştırmaktır. Bu kapsamda 3-9 yaş arası çocuğu olan 680 ebeveyn ile görüşülmüş ve ebeveynlere çocuğunun kişilik özelliklerini açıklayabilecekleri sorular sorulmuş (örneğin; çocuğunuzu iyi tanıyabilmemiz için bize ne söyleyebilirsiniz? gibi) ve çocuklarının karakterlerinin nasıl olduğunu anlatan bir hikâye yazmaları istenmiştir. Sonuç olarak ebeveynlerin karakter tanımlamaları; sevgi, nezaket, yaratıcılık, mizah, merak, öğrenme hevesi ve sebat (perseverance) üzerine yoğunlaşmıştrr. Mutluluk ile anlamlı ilişki içinde olan güçlü yönler ise sevgi, coşkulu olma ve umut olarak belirtilmiştir. Yapılan bu çalışma, karakter güçlerindeki bireysel farklılıkların üç yaşından itibaren ortaya çıkabileceğini kanıtlar niteliktedir (Park \& Peterson, 2006b). Karakterin bazı güçlü yönleri, belki de en görünür olanları, gelişim alanında çalışan daha fazla araştırmacının ilgisini çekmiştir. Örneğin, erken çocukluk döneminde kişilik tanımlarının ana kategorileri olarak nezaket, sevgi, takım çalışması, öz düzenleme, kararlılık, merak ve yaratıcılık üzerine önemli araştırmalar yapılmıştır. Öte yandan, açık görüşlülük, dürüstlük, alçakgönüllülük, güzelliğin takdir edilmesi ve affetme gibi bazı karakter güçlerinin erken çocuklukta var olduklarına dair kanıtlara (Park \& Peterson, 2006b) rağmen yapılan araştırmalar halen sınırlıdır.

İlkokul çağındaki çocukların karakter güçlerini belirlemeye yönelik yapılan bir araştırmada Çocuklar İçin Karakter Güçleri Ölçeği (CSI-C) geliştirilmiştir. Bu envanter, doğrudan çocukların kendilerinden toplanan veriler için tasarlanmış bir karakter analizi envanteridir. Peterson ve Seligman'nın (2004) karakter güçleri sınıflandırmasından yola çıkılarak hazırlanan envanterde 24 karakter gücü değerlendirmesi sunulmaktadır. 7-12 yaşlarındaki 2.061 
çocuktan toplanan veriler, envanterin güvenilir bir ölçme aracı olduğunu ortaya koymaktadır. Yapılan analizler sonucunda 96 maddelik CSI-C'nin temel bileşenler analizi ve doğrulayıcı faktör analizleri sonucunda dört üst faktörün içine yerleşen 24 düşük faktörlü hiyerarşik bir yapısı olduğu ortaya çıkmıştır. Bu dört faktör; Kişilerarası, entelektüellik, ölçülü olma ve aşkınlık olarak nitelendirilmiştir. Araştırma sonucunda çocukların kişilerarası ve aşkınlık güçleri, ruh sağlığı problemleri ile negatif ilişkili; ölçülü olma ve aşkınlık güçleri ise öznel iyi oluşları ile pozitif ilişkili olduğu bulunmuştur (Shoshani \& Shwartz, 2018). Bir başka araştırmada Shoshani ve Aviv (2012), çocukların ilkokula geçişte okula uyumları ile karakter güçleri arasındaki ilişkiyi incelemişlerdir. Bu araştırma ile ebeveynlerin ve çocukların karakter güçleri ile çocuğun akademik zorluklarla başa çıkabilme, yeni okul ve öğretmen beklentilerini karşılayabilme ve yeni bir akran grubuna kabul edilme becerisi arasında önemli ilişkiler olduğunu ortaya koymuşlardır.

Karakter güçleri ile ilgili araştırmalar son yıllarda artmış olmasına rağmen, çocukların karakter güçlerinin değerlendirilmesi için uygun niceliksel araçların olmayışı, çocukluk çağında karakter gelişimine ilişkin çalışmaları sınırlandırmaktadır (Shoshani \& Shwartz, 2018). Karakterlerin güçlü yanlarına dayalı (strengths-based) değerlendirme, kişisel başarı duygusunu geliştiren, aile üyeleri, akranlar ve yetişkinlerle destekleyici ve tatmin edici ilişkilere katkıda bulunan duygusal ve davranışsal becerilerin, yeterliliklerin ve özelliklerin ölçülmesini sağlayan bir değerlendirme şeklidir (Epstein, 2004). Öz değerlendirme raporlarına dayanan karakter güçleri envanterleri yetişkin ve genç bireylerde sıklıkla kullanılmaktadır (Rashid vd., 2013). Erken çocukluk dönemindeki çocukların karakter güçlerini belirlemede ise çocukların büyüdüğü çevredeki yetişkinlerden faydalanılmaktadır.

\subsection{Karakter Güçleri Envanteri Erken Çocukluk Formu’na (KGE-EÇ) ilişkin kuramsal çerçeve}

Shashoni (2018) tarafından geliştirilen envanterde, Peterson ve Seligman'nın (2004) ortaya koydukları 24 karakter gücü sınıflamasını temel alan teorik çerçeve esas alınmıştır. Ebeveyn raporlarına dayanan bulgular, erken çocukluk dönemindeki yirmi dört karakter gücü ifadesine ilişkin kanıtlar sağlamıştır. Peterson ve Seligman'nın (2004) ortaya koydukları yirmi dört karakter gücü bu araştırmada yapılan ikinci düzey faktör analizi ile dört faktörle açıklanmıştır. Bu dört faktör, çocukların karakter güçlerini ve erdemlerini geliştirmek için oluşturulabilecek dört farklı yolu işaret etmektedir. Bunlar, kişilerarası güçler, entelektüel güçler, ölçülülük ve aşkınlık erdemlerinden oluşmaktadır (Shashoni, 2018). Tablo 3'te envanterin ortaya koyduğu dört temel boyut ve bu boyutları oluşturan yirmi dört karakter gücü yer almaktadır.

\section{Tablo 3.}

Karakter Güçleri Envanteri Erken Cocukluk Formunun Boyutları

\begin{tabular}{lllll}
\hline Boyutlar & Kişilerarası Güçler & Entelektüel Güçler & Ölçüllülük & Aşkınlık \\
\hline & Sosyal zeka & & & \\
& Sevme ve sevilme & & İhtiyatlılı (Tedbirli olma) & Coşkulu olma \\
& Nezaketli olma & Öğrenme hevesi & Öz düzenleme & Minnettarlık \\
& Adalet & Merak & Affetme & Maneviyat \\
Karakter Güçleri & Takım çalışması & Güzellikleri takdir etme & Açı fikirlilik & Umut \\
& Bakış açısı & Yaratıcılık & Alçakgönüllülük & Mizah \\
& Liderlik & & Kararlılık & Dürüstlük \\
& Cesur olma & & & \\
\hline
\end{tabular}

Karakter güçlerini açıklayan dört temel boyuttan biri olan entelektüel güçler öğrenme hevesi, merak, güzellik ve bilginin takdiri ve yaratıcılık gibi güçlü yanları içermektedir. Park ve Peterson (2010) bu güçlü yönleri “aklın güçlü yanları" olarak tanımlamıştır. İkinci faktör "kalbin güçlü yanlarını” içeren kişilerarası güçlerdir (Park \& Peterson, 2010). Bu güçlü yönler kişilerarası ilişkileri desteklemekte, sevme ve sevilme, nezaketli olma, takım çalışması, liderlik, cesur olma, bakış açısı, adalet ve sosyal zekâ gibi güçlü yönleri içermektedir. Üçüncü faktör, çocuğun duruma bağlı olarak davranışını başlatma veya ondan vazgeçme kabiliyeti ile ilişsili olan ölçülü olmadır. Bu faktör öz düzenleme, alçakgönüllülük, affetme, ihtiyatlılık ve kararlılık gibi güçlü yönleri içermektedir. Dördüncü faktör olan aşkınlık erdemi, anlam ve gerçekliğin olumlu bir yorumunu sağlayan güçleri içermektedir. Bu boyut maneviyat, umut, minnettarlık, mizah, coşkulu olma ve dürüstlük gibi güçlü yönleri içerir (Shashoni, 2018).

\subsection{Araştırmanın amacı}

$\mathrm{Bu}$ araştırmanın amacı, Shoshani (2018) tarafından yapılan çalışma ile erken çocukluk dönemindeki çocukların karakter güçlerini belirlemeye yönelik geliştirilen envanteri Türkçeye uyarlamak, böylece erken çocukluk dönemindeki çocukların karakter güçlerini belirleyecek geçerli ve güvenilir bir ölçme aracı elde etmektir.

\subsection{Araştırmanın önemi}

Türkiye'de dünyada olduğu gibi son yıllarda karakter eğitimine verilen önem artsa da hala karakter güçlerini tanımlayan bir sınıflandırma bulunmamaktadır (Kabakçı, 2016). Ayrıca Türk kültüründe karakter güçlerine yönelik geliştirilmiş ölçme araçları sınırlıdır. Ölçme aracı olarak Kabakçı (2016) tarafından lise öğrencilerinin 
karakter güçlerini belirlemek amacıyla Karakter Güçleri ve Erdemli Oluş Gençlik Envanteri Türk kültüre uyarlamıştır. Ancak diğer yaş grupları ve erken çocukluk dönemindeki çocukların karakter güçlerini belirleme amacıyla geliştirilmiş ya da Türk kültürüne uyarlanmış bir ölçme aracı yoktur. Bu bağlamda erken çocukluk dönemindeki çocukların güçlü yönlerini belirlemeyi amaçlayan bir ölçme aracına ihtiyaç olduğu fark edilmiş ve bu çalışma bu ihtiyacı gidermek amacıyla tasarlanmıştır. Shoshani (2018) tarafından geliştirilen erken çocukluk dönemindeki çocukların karakter güçlerini belirlemeyi amaçlayan Karakter Güçleri Envanteri Erken Çocukluk Formu'nun Türkçeye uyarlama çalışmasının yapılarak Türk kültürüne kazandırılması açısından bu çalışma önemli görülmektedir.

\section{YÖNTEM}

\subsection{Katılımcılar}

Bu araştırmada 2017-2018 Eğitim-Öğretim yılı bahar döneminde Burdur İl Milli Eğitim Müdürlüğüne bağlı ilkokul anasınıfları ve bağımsız anaokullarında öğrenim gören 4-6 yaş çocukların ebeveynlerinden veri toplanmıştır. Veriler aile başına tek bir ebeveynden toplanmıştır. Araştırmaya katılan 311 ebeveynin \%79.1'i $(n=246)$ kadın iken \%20.9'u (n=65) erkektir. Çocukların \%44’ü (n=137) kı, \%55.9'u (n=174) erkektir. Çocukların yaşlarına göre dağılımlarına bakıldığında \%10.9’u (n=34) dört, \%30.9'u (n=96) beş, \%53'ü (n=165) altı ve yedi yaşlarındadır.

\subsection{Türkçeye uyarlanan ölçme aracı}

Bu araştırmada Shoshani (2018) tarafından geliştirilen erken çocukluk dönemindeki çocukların karakter güçlerini belirlemeyi amaçlayan Karakter Güçleri Envanteri-Erken Çocukluk Formu'nun Türkçe geçerlik ve güvenirlik çalışması yapılmıştır. Aşağıda uyarlaması yapılan orijinal ölçme aracı hakkında detaylı bilgilere yer verilmiştir.

\subsubsection{Karakter Güçleri Envanteri Erken Çocukluk Formu}

Karakter Güçleri Envanteri Erken Çocukluk Formu, Shoshani (2018) tarafindan VIA karakter güçleri sınıflandırmasının (Peterson \& Seligman, 2004) tanımladığı şekilde erken çocukluk dönemindeki çocukların (3-6 yaş) 24 karakter gücünü ölçmeyi amaçlayan bir envanter olarak geliştirilmiştir. Geliştirilen envanter 96 maddeden oluşmaktadır. Envanter entelektüel güçler, kişilerarası güçler, ölçülülük güçleri ve aşkınlık güçleri olmak üzere 4 faktör ve 24 alt boyuttan oluşmaktadır. Bu boyutlar sosyal zekâ, sevme ve sevilme, nezaketli olma, adalet, takım çalışması, bakış açısı, liderlik, cesur olma, öğrenme hevesi, merak, güzellikleri takdir etme, yaratıcılık, ihtiyatlılık (tedbirli olma), öz düzenleme, affetme, açık fikirlilik, alçakgönüllülük, kararlılık, coşkulu olma, minnettarlık, maneviyat, umut, mizah, dürüstlük şeklindedir.

Ölçek 5'li likert ölçeğidir (1= Kesinlikle Katılmıyorum, 2= Katılmıyorum, 3= Ne Katılıyorum Ne Katılmıyorum, 4= Katılıyorum, 5= Kesinlikle Katılıyorum). Anne babalardan her bir madde için çocuklarını en iyi tanımlayan seçeneği işaretlemeleri istenmiştir. Envanterde olumsuz madde bulunmamaktadır. Envanter her bir karakter gücü için ayrı puan vermektedir ve her bir karakter özelliğini belirlemeyi hedeflediği için toplam puan alınması uygun değildir.

\subsubsection{Orijinal envanterin geliştirilme süreci}

Envanter geliştirme çalışması kapsamında araştırmacılar 3-6 yaş arası çocukları olan 2274 ebeveyni çalışmaya dahil etmişlerdir. İsrail'deki farklı şehir merkezlerinden veriler toplanmıştır. Veriler aile başına tek bir ebeveynden elde edilmiştir. Ölçme aracı, tamamıyla teoriye dayalı bir envanterdir. Maddelerin oluşturulmasından önceki aşamada araştırma ekibi 24 karakter gücü için ebeveynler, okul öncesi öğretmenler ve alan uzmanları ile çocukların ailedeki ve akran gruplarındaki gerekli davranış ve durumları ile ilgili görüşmeler yapmışlardır. Ayrıca tüm araştırma ekibi VIA sınıflaması ile ilgili eğitimler almışlardır. Ölçek geliştirme ekibi karakter güçlerinin teorik çerçevesini göz önünde bulundurarak başlangıçta 144 madde yazmışlardır. Ancak yapılan analizler sonrasında bazı maddelerin atılması uygun görülmüş ölçme aracının nihai hali 96 madde olarak belirlenmiştir (Shoshani, 2018).

\subsubsection{Orijinal envanterin geçerlik ve güvenirlik çalışmaları}

Ölçeğin yapı geçerliği açımlayıcı ve doğrulayıcı faktör analizi ile incelenmiştir. Faktör yapısını ortaya koymak amacıyla yapılan açımlayıcı faktör analizi toplam varyansın \%64.44'ünü ortaklaşa oluşturan 24 farklı faktör ortaya koymuştur. Her bir maddenin kendi 24 farklı alt boyutu ile korelasyonları 0,40 ile 0,82 arasında değişmiştir. İkinci aşamada, birinci aşamadaki 24 alt boyut değişken olarak kullanılarak ikinci dereceden faktör analizi yapılmıştır. Oblimin rotasyonu ile dört faktörlü faktör analizi yapılmıştır. Kümülatif olarak, dört faktör toplam varyansın \%57.90'ını açıklamıştır. Ortaya çıkan dört faktör, Park ve Peterson (2006b) tarafindan VIA-Gençler için olan 
formu, ölçeğinin orijinal faktör analizinde bildirilen faktörlere kavramsal olarak benzemektedir ve bu faktörler şu şekilde isimlendirilmiştir: Entelektüel güçler, kişilerarası güçler, ölçülülük güçleri ve aşkınlık güçleridir. Karakter güçlerinden sevme ve sevilme, merak ve yaratıcılık güçlü yönleri sırasıyla en yüksek puanlara sahipken maneviyat, bakış açısı ve alçakgönüllülük en düşük ortalama puanlara sahiptir (Shoshani, 2018).

Açımlayıcı faktör analizinde tanımlanan faktör yapısının güvenirliğini belirlemek için 1137 katılımcıdan elde edilen ikinci veri setine doğrulayıcı faktör analizi uygulanmıştır. Değerlendirilen ilk model açımlayıcı faktör analizi ile tanımlanan 24 faktörlü modeldir. Bu model kabul edilebilir bir uyum göstermiştir $(\mathrm{TLI}=0.901, \mathrm{CFI}=$ 0.905, SRMR = 0.051, RMSEA = 0.041). Test edilen ikinci model, 24 güçlü alt ölçeğin temsil ettiği dört faktörlü model ve dört gizil faktörün (Entelektüel Güçler, Kişilerarası Güçler, Ölçülülük Güçleri ve Aşkınlık Güçleri) birbirleriyle ilişkileridir. Test edilen ikinci model de kabul edilebilir model uyum indekslerine (TLI $=0.90$, CFI $=0.92$, SRMR $=0.054$, RMSEA $=0.075)$ sahiptir. Shoshani (2018) tarafından yapılan açımlayıcı ve doğrulayıcı faktör analizi sonuçları ölçme aracının faktör yapısının uygun olduğunu göstermektedir.

Shoshani’nin (2018) çalışmasında yer alan güvenirlik analizi sonuçlarına göre her bir alt boyutun Cronbach alfa katsayıları 0.74 ile 0.92 aralığında değer ortaya koymaktadır. $\mathrm{Bu}$ da ölçme aracının güvenirliğinin yüksek olduğunu göstermektedir.

\section{3. Ölçeğin uyarlama aşamaları}

Ölçek uyarlama çalışmasının yapılabilmesi için envanteri geliştiren Anat Shoshani ile e-posta yolu ile iletişime geçilmiş ve envanterin Türkçe uyarlaması için gerekli izin alınmıştır. Orijinal formu İngilizce olan ölçme aracı, İngilizce alanında uzman üç kişi tarafından ayrı ayrı Türkçeye çevrilmiştir. Bu çeviriler İngilizce bilen okulöncesi eğitimi ve psikolojik danışma ve rehberlik alanında uzman iki kişi tarafından incelenmiş ve aralarındaki benzerlik ve farklılıklar belirlenmiştir. Çeviriler arasında yüksek düzeyde uyum olduğu görülmüştür. Ölçme aracının kültürel olarak uygunluğu, alan uzmanı iki kişi ile değerlendirilmiş ve maddeler üzerinde gerekli düzenlemeler yapılmıştır. Ayrıca araştırmacılar okul öncesi dönemde çocuğu olan sekiz ebeveyn ile ölçek maddelerinin anlaşılırlığı üzerine görüşmeler yapmıştır. Böylece envanterin 96 maddelik deneme formu oluşturulmuştur. Ardından Türkçeye çevirisi yapılan envanter formunun geri çeviri aşamasına geçilmiştir. Ölçme aracı İngilizceye hâkim iki alan uzmanı tarafından yeniden İngilizceye çevrilmiştir. Geri çeviriler envanterin asıl formu ile kıyaslanmış ve ifadelerin asıl form ile uyumlu olduğu görülmüştür.

Deneme formunun oluşturulmasının ardından Burdur İl Milli Eğitim Müdürlüğü’nden İl Milli Eğitim Müdürlüğüne bağlı okulöncesi eğitim kurumlarında öğrenim görmekte olan çocukların ebeveynlerine envanter uygulanabilmesi için gerekli yasal izinler alınmıştır. Okullarda görev yapan okulöncesi öğretmenleri ile görüşülerek her aileden tek bir ebeveynin formu doldurması koşuluyla envanterleri velilere ulaştırmaları rica edilmiştir. Araştırmacılar da okulları tekrar dolaşarak doldurulan envanterleri geri toplamışlardır.

\subsection{Verilerin analizi}

Envanterin yapısının orijinal ölçme aracının yapısı ile benzerliği doğrulayıcı faktör analizi ile test edilmiştir. Alan yazına göre önsel bir bilginin olmadığı durumlarda açımlayıcı faktör analizi (AFA), var olan bir kuramın ya da yapının test edilmesinde ise doğrulayıcı faktör analizi (DFA) kullanılmaktadır. Bu bilgiden yola çıkarak test geliştirme süreci için AFA, uyarlama için ise DFA daha uygun görünmektedir (Kline, 2005). Bu uyarlama çalışmasında da orijinal ölçek belirli bir faktör yapısına sahip olduğu için doğrulayıcı faktör analizinin kullanılması yeterli görülmüştür. Envanterin güvenirliğini belirlemek için ise Cronbach alfa katsayısı, düzeltilmiş madde toplam korelasyonu değerleri incelenmiştir. Doğrulayıcı faktör analizi LISREL 8.7 programından, güvenirlik analizleri ise SPSS 21 programından faydalanılarak yapılmıştır.

\section{BULGULAR}

Orijinal envanterin Türk örneklemindeki geçerlik ve güvenirlik analizlerinin sonuçları aşağıda yer almaktadır.

\subsection{Doğrulayıcı faktör analizine ilişkin bulgular}

Orijinal envanterin faktör yapısı ile Türkçe formunun faktör yapısı arasındaki uyumu belirlemek amacıyla Lisrel 8.7 programı kullanılarak doğrulayıcı faktör analizi yapılmıştır. 96 madde ve 24 faktörden oluşan ölçme aracının madde ve faktör sayısı fazla olduğu için LİSREL programı path diyagramının görüntülenmesine müsaade etmemiştir. $\mathrm{Bu}$ nedenle bulgulara path diyagramı eklenememiştir, sadece test edilen modellerin model uyum indekslerine yer verilmiştir.

Öncelikle orijinal ölçme aracının ortaya koyduğu 24 alt boyuttan oluşan yapı, birinci düzey doğrulayıcı faktör analizi ile test edilmiştir. Test edilen modelin model uyum indeksleri $\left(\mathrm{x}^{2} / \mathrm{sd}=2.32, \mathrm{NNFI}=0.93, \mathrm{CFI}=0.94, \mathrm{SRMR}\right.$ $=0.065$, RMSEA $=0.065)$ incelendiğinde modelin kabul edilebilir uyum gösterdiği belirlenmiştir (Tabachnick \& 
Fidell, 2015). Böylece orijinal ölçme aracında yer alan erken çocukluk dönemi karakter güçlerini belirlemeyi amaçlayan 96 madde ve bu maddelerin oluşturduğu 24 faktörlü yapı Türk kültüründe de doğrulanmıştır.

Orijinal ölçme aracında 24 karakter gücünün 4 temel erdemi açıkladığı görülmektedir. Bu yapıyı test etmek amacıyla birinci düzey doğrulayıcı faktör analizine ek olarak ikinci düzey doğrulayıcı faktör analizi yapılmıştır. İkinci düzey doğrulayıcı faktör analizi ile modele dört temel erdem de eklenerek 24 alt boyutun temsil ettiği dört faktörlü model (Entelektüel, Kişilerarası, Ölçülülük, Aşkınlık) test edilmiştir. Test edilen modelin model uyum indekslerinin $\left(\mathrm{x}^{2} / \mathrm{sd}=2.58, \mathrm{NNFI}=.0 .93, \mathrm{CFI}=0.93, \mathrm{SRMR}=0.076, \mathrm{RMSEA}=0.071\right)$ yeterli düzeyde olduğu görülmüştür (Tabachnick \& Fidell, 2015).

Birinci ve ikinci düzey doğrulayıcı faktör analizi sonuçları Karakter Güçleri Envanteri Erken Çocukluk Formu'nun 3-6 yaş çocuklarının karakter güçlerini belirlemede geçerli bir ölçme aracı olduğunu göstermektedir. Ancak ölçeğin Türkçeye uygunluğundan bahsedebilmek için geçerlik bilgilerinin yanı sıra güvenirlik bilgilerine de ihtiyaç vardır. Aşağıda ölçme aracının güvenirlik bilgilerine yer verilmiştir.

\section{2. Ölçeğin güvenirliğine ilişkin bulgular}

Karakter Güçleri Envanteri Erken Çocukluk Formu'nda yer alan 96 maddenin güvenirliğini test etmek için Cronbach alfa iç tutarlık katsayısı hesaplanmıştır. Tablo 4'te envanterden elde edilen Cronbach alfa iç tutarlılık katsayıları verilmiştir.

\section{Tablo 4.}

Güçlerin Faktörlerine İlişkin Cronbach Alfa İç Tutarlık Katsayıları

\begin{tabular}{lcc}
\hline Faktörler & Madde sayısı & Güvenirlik Katsayısı (a) \\
\hline Kişilerarası & 32 & 0.91 \\
Entelektüellik & 16 & 0.86 \\
Ölçülülük & 24 & 0.88 \\
Aşkınlık & 22 & 0.89 \\
\hline
\end{tabular}

Dört faktörlü envanterin; kişilerarası faktörü için hesaplanan Alfa iç tutarlık katsayı 0.91; entelektüellik faktörü için hesaplanan iç tutarlık katsayı 0.86 ; ölçülülü̈k faktörü için hesaplanan iç tutarlık katsayısı 0.88 ve aşkınlık faktörü için 0.89 olarak bulunmuştur. Testler için hesaplanan güvenirlik katsayılarının 0.70 ve daha yüksek olması ölçeğin test puanlarının güvenilirliği için yeterli görülmektedir (Büyüköztürk, 2007).

Ölçekte yer alan maddelerin ölçtükleri özellik açısından kişileri ayırt etmede ne kadar başarılı olduklarını belirlemek ve testin iç tutarlılı̆̆ını araştırmak amacıyla, düzeltilmiş madde toplam korelasyonu hesaplanmış ve toplam puana göre belirlenmiş \% $27^{\prime}$ lik üst ve alt grupların madde puanları arasında anlamlı bir fark olup olmadığ 1 t-testi ile incelenmiştir. Tablo 5 'te faktörlerin düzeltilmiş madde toplam korelasyonları ve üst \%27 ile alt \%27'lik grupların puanları arasındaki t-testi sonuçları verilmiştir.

\section{Tablo 5.}

Faktörlerinin Düzeltilmiş Madde Toplam Korelasyonları ve Üst \%27, Alt \%27'lik Grupların Puanları Arasındaki t Testi Sonuçları

\begin{tabular}{lll}
\hline Faktör Adı & Madde No & t (üst \%27- alt \%27) \\
\hline Kişilerarası & 32 & $-33.73^{* *}$ \\
Entelektüellik & 16 & $-33.25^{* *}$ \\
Ölçülülük & 24 & $-34.15^{* *}$ \\
Aşkınlık & 22 & $-30.25^{* *}$ \\
\hline
\end{tabular}

Ebeveynlerden elde edilen verilere ayrıca madde analizi uygulanmıştır. Tüm maddeler için 0.05 anlamlılık düzeyinde anlamlı bir ilişki bulunmuştur. Her bir maddenin düzeltilmiş madde-toplam korelâsyon katsayıları 0.15 ile 0.86 arasında değişmektedir. t testi sonuçları ise \%27'lik üst ve alt \%27'lik grupların madde ortalamaları arasındaki tüm farkların anlamlı olduğunu göstermektedir.

\section{TARTIŞMA ve SONUÇ}

$\mathrm{Bu}$ araştırma ile Shashoni (2018) tarafından geliştirilen ve erken çocukluk dönemindeki çocukların karakter güçlerini belirlemeyi hedefleyen Karakter Güçleri Envanteri Erken Çocukluk Formu'nun Türkçeye uyarlama çalışması yapılarak erken çocukluk dönemindeki çocukların karakter güçlerinin belirlenmesini sağlayacak geçerli ve güvenilir bir ölçme aracının elde edilmesi hedeflenmiştir. Elde edilen bulgular Karakter Güçleri Envanteri Erken Çocukluk Formu'nun Türkçeye uyarlanması sonucunda orijinal envantere benzer şekilde 96 madde, 24 faktör ve bu faktörleri kapsayan 4 temel boyuttan oluştuğunu göstermektedir. Karakter güçlerini gösteren 24 boyut şu şekildedir: Sosyal zekâ, sevme ve sevilme, nezaketli olma, adalet (hakkaniyet), takım çalışması, bakış açısı, liderlik, cesur olma, öğrenme hevesi, merak, güzellikleri takdir etme, yaratıc1lı, ihtiyatlllık (tedbirli olma), öz düzenleme, affetme, açık fikirlilik, alçakgönüllüllük, kararlılık, coşkulu olma, minnettarlık, maneviyat, umut, 
mizah ve dürüstlüktür. Bu karakter güçlerinin birlikte açıkladıkları 4 temel boyut ise, kişilerarası güçler, entelektüel güçler, ölçülülük ve aşkınlık güçlü yönlerinden oluşmaktadır. Ancak ilgili alan yazında karakter güçleri ve erdemleri ölçmeyi amaçlayan ölçme araçları 24 karakter gücü konusunda benzer bulguları ortaya koymalarına rağmen bu güçler her zaman 4 boyutta toplanmamıştır. Karakter güçlerinin farklı yaş gruplarındaki örneklem gruplarında farklı boyutlarda gruplandığ 1 ve bu araştırmalarda boyutların isimlerinin farklılaştığı görülmüştür (Brdar \& Kashdan, 2010; Littman-Ovadia \& Lavy 2012; McGrath, 2014; Ruch vd., 2010).

Mevcut araştırmada envanterin orijinal formu ve uyarlama formu arasındaki yapı benzerliğinin ortaya koyulması amacıyla birinci ve ikinci düzey doğrulayıcı faktör analizi yapılmıştır. Elde edilen birinci düzey doğrulayıcı faktör analizi indeksleri $\left(\mathrm{x}^{2} / \mathrm{sd}=2.32\right.$, NNFI $=.0 .93, \mathrm{CFI}=0.94$, SRMR $\left.=0.065, \mathrm{RMSEA}=0.065\right)$ ve ikinci düzey doğrulayıcı faktör analizi indeksleri $\left(\mathrm{x}^{2} / \mathrm{sd}=2.58, \mathrm{NNFI}=.0 .93, \mathrm{CFI}=0.93, \mathrm{SRMR}=0.076, \mathrm{RMSEA}=0.071\right)$ modelin iyi düzeyde uyum gösterdiğini ortaya koymaktadır. Orijinal envanterdeki model uyum indeksleri ile mevcut araştırmadaki model uyum indeksleri benzerlik göstermektedir. Tablo 6'da her iki uygulamanın model uyum indekslerine karşılaştırmalı olarak yer verilmiştir.

\begin{tabular}{llllll}
\hline \multicolumn{7}{l}{ Tablo 6. } \\
\multicolumn{7}{l}{ Orijinal Envanter ve Uyarlama Envanteri Model } & Uyum Indekslerinin Karşılaştırılmasl & \\
\hline \multicolumn{7}{l}{} \\
\hline Orijinal Makale 1. Düzey DFA & TLI (NNFI) & CFI & SRMR & RMSEA & $\mathbf{x}^{2} / \mathbf{s d}$ \\
Uyarlama Çalışmas1 1. Düzey DFA & 0.901 & 0.90 & 0.051 & 0.041 & Belirtilmemiş \\
Orijinal Makale 2. Düzey DFA & 0.90 & 0.94 & 0.065 & 0.065 & 2.32 \\
Uyarlama Çalışmas1 2. Düzey DFA & 0.93 & 0.924 & 0.054 & 0.075 & Belirtilmemiş \\
\hline
\end{tabular}

Tablo 6'da görüldüğü gibi orijinal çalışma ve uyarlama çalışması kıyaslandığında hem birinci düzey DFA hem de ikinci düzey DFA sonuçları benzer ve iyi düzeyde uyum indekslerine sahiptir. Doğrulayıcı faktör analizi sonuçları ölçme aracının yapı geçerliğine sahip olduğunu doğrulamaktadır. Envanterin güvenirliğine ilişkin bulgular incelendiğinde, orijinal ölçme aracının boyutlarının Cronbach alfa iç tutarlılık katsayıları 0.74 ile 0.92 aralığında değişirken, uyarlama çalışmasında bu değerlerin 0.86 ile 0.91 aralı̆ıında olduğu görülmüştür. $\mathrm{Bu}$ değerler uyarlaması yapılan ölçme aracının güvenilir olduğunu göstermektedir. Ayrıca testin iç tutarlılığını belirlemek amacıyla envanterin düzeltilmiş madde toplam korelasyonu hesaplanmış ve madde ortalamaları arasındaki farklar anlamlı bulunmuştur. Geçerlik ve güvenirlik analizlerine göre KGE-EÇ formunun, erken çocukluk dönemi çocuklarının karakter güçlerini belirlemede kullanılabilecek geçerli ve güvenilir bir ölçme aracı olduğu söylenebilir.

KGE-EÇ formu, erken çocukluk döneminde karakter güçlerinin ilk ifadelerini göstermekte ve erken çocukluk döneminde çocukların karakter güçlerini değerlendirmek için uzmanlar ve araştırmacılar için kullanımı kolay bir araç sağlamaktadır. Ayrıca, erken çocukluk dönemindeki karakter güçlerinin geniş bir kavramsal yapısını ve karakter güçlerinin farklı boyutlarını sunmaktadır. Karakterin farklı boyutlarının farkında olma ve bu boyutları kişilik oluşumunun ilk evrelerinde çocuk yetiştirme ve eğitme süreçlerinde vurgulamak, davranışsal ve duygusal sorunları hafifletebilecek ve iyi oluşu artırabilecek kaynaklar oluşturabilir (Shoshani, 2018). Böylece çocukların karakter güçlerinin erken yaşlarda belirlenmesinin önleyici çalışmalarda yol gösterici olması beklenmektedir.

Gelişimsel olarak erken çocukluk dönemine göre tasarlanan sınıf uygulamalarının çoğu karakter eğitiminin hedeflerini destekler. Karakter özellikleri ve karakterin güçlendirilmesi kapsamlı bir program planlarken göz önünde bulundurulmalıdır. Erken çocukluk döneminde sunulan bu eğitimler çocuğun karakterini, karakter gelişiminin kritik döneminde desteklemek için büyük bir firsat sunar (Priest, 2007). Okullarda karakter eğitimi sistematik olarak sunulabilecek etkin bir birincil önleme şeklidir. Nitekim yapılan araştırmalar karakter eğitimi programlarının şiddet ve madde kullanımında önemli düşüşlere yol açtığını göstermektedir (Battistich vd., 2000). Uygulanan karakter eğitimlerinin etkililiğinin kanıtlanabilmesi için çocukların karakter özelliklerini ve düzeyini ölçebilecek araçların artmasına ihtiyaç vardır. Ayrıca iyi karakterli ve başarılı bir gençlik geliştirmek için etkili araçlar oluşturma çalışmaları araştırmacılar ve eğitimciler arasındaki işbirliğini teşvik etmede önemlidir.

Elde edilen bulgular erken çocukluk dönemindeki çocukların karakter güçlerini belirlemede Karakter Güçleri Envanteri Erken Çocukluk Formu'nun Türk kültüründe geçerli ve güvenilir bir ölçme aracı olduğunu göstermektedir. Yurt içi alan yazın incelendiğinde küçük çocukların karakter güçlerini belirleyen bir ölçme aracı olmadığı görülmüsşür. Bu nedenle bu çalışmanın alana katkı sağlayacağı düşünülmektedir. Ayrıca envanterin farklı örneklem gruplarında geçerlik ve güvenirlik analizlerinin tekrarlanması ölçme aracının güvenirliğini daha da kuvvetlendireceği düşünülmektedir. Alan yazında karakter güçleri ile farklı yaşlardaki bireylerin okul başarısı (Lounsbury vd., 2009; Shoshani \& Slone, 2013) iyi oluş (Martínez-Martí \& Ruch, 2014; Proctor vd., 2011; Shoshani, 2018; Shoshani \& Slone, 2013) depresyon (Gillham vd., 2011; Kim vd., 2018; Tehranchi vd., 2018) gibi farklı değişkenler arasındaki ilişkiler ele alınmıştır. Benzer şekilde bundan sonraki araştırmalarda Türkiye'de erken çocukluk dönemindeki çocukların karakter güçleri ile ilişkili olabilecek değişkenler belirlenip aralarındaki ilişkiler araştırılabilir. Çocukların karakter özelliklerinin belirlenmesi araştırmacılar için güvenilir veriler sağlamasının yanı sıra ebeveynlere çocuklarının, öğretmenler ve okul rehberlik hizmetlerine öğrencilerinin 
karakter profillerini ortaya koymada yol gösterici olacaktır. Bunun yanı sıra çocukların karakter özelliklerinin ölçülebilir olması çocuklara sunulacak hizmetlerde karakter özelliklerinin de dikkate alınmasına katkı sağlayacağı ve gelişiminin takip edilmesini kolaylaştıracağı düşünülmektedir. 


\section{KAYNAKÇA}

Battistich, V., Schaps, E., Watson, M., Solomon, D., \& Lewis, C. (2000). Effects of the child development project on students' drug use and other problem behaviors. Journal of Primary Prevention, 21(1), 75-99. https://doi.org/10.1023/A:1007057414994

Baker, L., Green, S., \& Falecki, D. (2017). Positive early childhood education: Expanding the reach of positive psychology into early childhood. European Journal of Applied Positive Psychology, 1(8), 1-12.

Beaty, J. J. (1999). Prosocial guidance for the preschool child. Prentice-Hall.

Becker, J. A., \& Smenner, P. C. (1986). The spontaneous use of thank you by preschoolers as a function of sex, socioeconomic status, and listener status. Language in Society, 15, 537-545.

Brdar, I., \& Kashdan, T. B. (2010). Character strengths and well- being in Croatia: An empirical investigation of structure and correlates. Journal of Research in Personality, 44, 151-154. https://doi.org/10.1016/j.jrp.2009.12.001

Brownell, C. A., Zerwas, S., \& Ramani, G. B. (2007). So big: The development of body self-awareness in toddlers. Child Development, 78, 1426-1440. https://doi.org/10.1111/j.1467-8624.2007.01075.x

Büyüköztürk, Ş. (2007). Sosyal bilimler için veri analizi el kitabı. Pegem A Yayıncılık.

Corral-Verdugo, V., Tapia-Fonllem, C., \& Ortiz-Valdez, A. (2014). On the relationship between character strengths and sustainable behavior. Environment and Behavior, 47(8), 877-901. https://doi.org/10.1177/0013916514530718

Costin, S. E., \& Jones, D. C. (1992). Friendship as a facilitator of emotional responsiveness and prosocial interventions among young children. Developmental Psychology, 28(5), 941-947. https://doi.org/10.1037/0012-1649.28.5.941

Dunn, J. (1988). The beginnings of social understanding. Harvard University Press.

Eckerman, C. O., Davis, C. C., \& Didow, S. M. (1989). Toddlers' emerging ways of achieving social coordinations with a peer. Child development, 60(2), 440-453. http://dx.doi.org/10.2307/1130988

Eisenberg, N., \& Fabes, R. (1992). Emotion, regulation, and the development of social competence. In M. S. Clark (Ed.), Emotion and social behavior (pp. 119-150). Sage.

Epstein, M. H. (2004). Behavioral and emotional rating scale (2nd ed.). PRO-ED.

Gillham, J., Adams-Deutsch, Z., Werner, J., Reivich, K., Coulter-Heindl, V., Linkins, M., \& Seligman, M. E. P. (2011). Character strengths predict subjective well-being during adolescence. The Journal of Positive Psychology, 6(1), 31-44. https://doi.org/10.1080/17439760.2010.536773

Kabakçı, Ö. F. (2016). Karakter güçleri ve erdemli oluş: Güçlü yanlara-dayalı psikolojik danışma ve değerler eğitimine yeni bir yaklaşım. Türk Psikolojik Danışma ve Rehberlik Dergisi, 6(45), 25-40.

Kim, H. R., Kim, S. M., Hong, J. S., Han, D. H., Yoo, S. K., Min, K. J., \& Lee, Y. S. (2018). Character strengths as protective factors against depression and suicidality among male and female employees. BMC Public Health, 18(1), 1084. https://doi.org/10.1186/s12889-018-5997-1

Kline, R. B. (2005). Methodology in the social sciences. Principles and practice of structural equation modeling (2nd ed.). Guilford Press.

Littman-Ovadia, H., \& Lavy, S. (2012). Character strengths in Israel: Hebrew adaptation of the VIA Inventory of Strengths. European Journal of Psychological Assessment, 28(1), 41-50. https://doi.org/10.1027/10155759/a000089

Lounsbury, J. W., Fisher, L. A., Levy, J. J., \& Welsh, D. P. (2009). An investigation of character strengths in relation to the academic success of college students. Individual Differences Research, 7(1), 52-69.

Macdonald, C., Bore, M., \& Munro, D. (2008). Values in Action scale and the Big 5: An empirical indication of structure. Journal of Research in Personality, 42(4), 787-799. https://doi.org/10.1016/j.jrp.2007.10.003

Martínez-Martí, M. L., \& Ruch, W. (2014). Character strengths and well-being across the life span: Data from a representative sample of German-speaking adults living in Switzerland. Frontiers in Psychology, 5, 1253. https://doi.org/10.3389/fpsyg.2014.01253

McGrath, R. (2014). Scale- and item-level factor analyses of the VIA inventory of strengths. Assessment, 21(1), 4-14. https://doi.org/10.1177/1073191112450612

Moreno, A. J., \& Robinson, J. L. (2005). Emotional vitality in infancy as a predictor of cognitive and language abilities in toddlerhood. Infant and Child Development, 14(4), 383-402. https://doi.org/10.1002/icd.406

Park, N. (2004). Character strengths and positive youth development. The Annals of the American Academy of Political and Social Science, 591(1), 40-54. https://doi.org/10.1177/0002716203260079

Park, N., \& Peterson, C. (2006a). Moral competence and character strengths among adolescents: The development and validation of the values in action inventory of strengths for youth. Journal of Adolescence, 29(6), 891-909. https://doi.org/10.1016/j.adolescence.2006.04.011

Park, N., \& Peterson, C. (2006b). Character strengths and happiness among young children: Content analysis of parental descriptions. Journal of Happiness Studies, 7, 323-341. https://doi.org/10.1007/s10902-0053648-6 
Park, N., \& Peterson, C. (2009). Character strengths: Research and practice. Journal of College and Character, 10(4), 1-10. https://doi.org/10.2202/1940-1639.1042

Park, N., \& Peterson, C. (2010). Does it matter where we live? The urban psychology of character strengths. American Psychologist, 65(6), 535-547. https://doi.org/10.1037/a0019621

Park, N., Peterson, C., \& Seligman, M. E. P. (2004). Strengths of character and well-being: A closer look at hope and modesty. Journal of Social and Clinical Psychology, 23(5). 628-634. https://doi.org/10.1521/jscp.23.5.628.50749

Peterson, C. (2006). A primer in positive psychology. Oxford University Press.

Peterson, C., \& Seligman, M. E. P. (2004). Character strengths and virtues: A handbook and classification. Oxford University Press/American Psychological Association.

Peterson, C., Park, N., Pole, N., D'Andrea, W., \& Seligman, M. E. (2008). Strengths of character and posttraumatic growth. Journal of Traumatic Stress: Official Publication of the International Society for Traumatic Stress Studies, 21(2), 214-217. https://doi.org/10.1002/jts.20332

Priest, C. (2007). Incorporating character education into the early childhood degree program: The need, and one department's response. Journal of Early Childhood Teacher Education, 28(2), 153-161. https://doi.org/10.1080/10901020701366723

Proctor, C., Tsukayama, E., Wood, A. M., Maltby, J., Eades, J. F., \& Linley, P. A. (2011). Strengths gym: The impact of a character strengths-based intervention on the life satisfaction and well-being of adolescents. The Journal of Positive Psychology, 6(5), 377-388. https://doi.org/10.1080/17439760.2011.594079

Rashid, T., Anjum, A., Lennox, C., Quinlan, D., Niemiec, R. M., Mayerson, D., \& Kazemi, F. (2013). Assessment of character strengths in children and adolescents. In C. Proctor \& P. A. Linley (Eds.), Research, applications, and interventions for children and adolescents (pp. 81-115). Springer, Dordrecht.

Ruch, W., Proyer, R. T., Harzer, C., Park, N., Peterson, C., \& Seligman, M. E. P. (2010). Values in action inventory of strengths (VIA-IS): Adaptation and validation of the German version and the development of a peerrating form. Journal of Individual Differences, 31(3), 138-149. https://doi.org/10.1027/1614$0001 / \mathrm{a} 000022$

Seligman, M. E. P. (2002). Authentic happiness: Using the new positive psychology to realize your potential for lasting fulfillment. Free Press.

Seligman, M. E. P., \& Csikszentmihalyi, M. (2000). Positive psychology: An introduction. American Psychologist, 55(1), 5-14. http://dx.doi.org/10.1037/0003-066X.55.1.5

Seligman, M. E. P., Rashid, T., \& Parks, A. C. (2006). Positive psychotherapy. American Psychologist, 61(8), 774-788. https://doi.org/10.1037/0003-066X.61.8.774

Shoshani, A. (2018). Young children's character strengths and emotional well-being: Development of the character strengths inventory for early childhood (CSI-EC). The Journal of Positive Psychology, 14(1), 86-102. https://doi.org/10.1080/17439760.2018.1424925

Shoshani, A., \& Aviv, I. (2012). The pillars of strength for first-grade adjustment-Parental and children's character strengths and the transition to elementary school. The Journal of Positive Psychology, 7(4), 315-326. https://doi.org/10.1080/17439760.2012.691981

Shoshani, A., \& Shwartz, L. (2018). From character strengths to children's well-being: Development and validation of the Character Strengths Inventory for elementary school children. Frontiers in Psychology, 9, 2123. https://doi.org/10.3389/fpsyg.2018.02123

Shoshani, A., \& Slone, M. (2013). Middle school transition from the strengths perspective: Young adolescents' character strengths, subjective well-being, and school adjustment. Journal of Happiness Studies, 14(4), 1163-1181. https://doi.org/10.1007/s10902-012-9374-y

Shoshani, A., \& Slone, M. (2017). Positive education for young children: Effects of a positive psychology intervention for preschool children on subjective well being and learning behaviors. Frontiers in Psychology, 8, 1866. https://doi.org/10.3389/fpsyg.2017.01866

Shryack, J., Steger, M. F., Krueger, R. F., \& Kallie, C. S. (2010). The structure of virtue: An empirical investigation of the dimensionality of the virtues in action inventory of strengths. Personality and Individual Differences, 48(6), 714-719. https://doi.org/10.1016/j.paid.2010.01.007

Singh, K., \& Choubisa, R. (2010). Empirical validation of values in action-inventory of strengths (VIA-IS) in Indian context. National Academy of Psychology India Psychological Studies, 55, 151-158. https://doi.org/10.1007/s12646-010-0015-4

Tabachnick, B. G., \& Fidell, L. S. (2015). Çok değişkenli istatistiklerin kullanımı (M. Baloğlu, Çev. Ed.) (6. baskıdan çev.). Nobel Yayıncılık.

Tehranchi, A., Doost, H. T. N., Amiri, S., \& Power, M. J. (2018). The role of character strengths in depression: A structural equation model. Frontiers in psychology, 9, 1609. https://doi.org/10.3389/fpsyg.2018.01609

Warneken, F., Chen, F., \& Tomasello, M. (2006). Cooperative activities in young children and chimpanzees. Child Development, 77(3), 640-663. https://doi.org/10.1111/j.1467-8624.2006.00895.x 
Wiley, J. (2000). Linking character development with academics. Kappa Delta Pi Record, 36(4), $163-167$. https://doi.org/10.1080/00228958.2000.10518778 


\section{EXTENDED ABSTRACT}

\section{INTRODUCTION}

The purpose of the current study is to adapt the Character Strengths Inventory for Early Childhood (2018) developed to determine the character strengths of children in their early childhood period into Turkish and thus to obtain a reliable and valid measurement tool to be used to determine children's character strengths in their early childhood. Although character and values education has not been widespread in Turkey, the absence of a measuring tool for determining the character strengths of children in their in early childhood has made it necessary to conduct the current adaptation study

\section{METHOD}

The original of the adapted measurement tool was developed by Shoshani (2018) as an inventory aiming to measure the 24 character strengths of early childhood children (3-6 years old) as defined by the VIA character strength classification. The scale is comprised of 94 items, 24 factors and 4 main dimensions under which the factors are gathered. The scale is a five-point Likert type scale $(1=$ Strongly Disagree, $2=$ Disagree, $3=$ Neither Agree nor Disagree, $4=$ Agree, $5=$ Strongly Agree). The validity studies of the original scale were performed by using exploratory and confirmatory factor analyses. The distribution of 96 items across 24 factors found with the exploratory factor analysis was confirmed with the confirmatory factor analysis (TLI $=0.901, \mathrm{CFI}=0.905$, SRMR $=0.051$, RMSEA $=0.041$ ). The four-dimension construct under which 24 factors are gathered was tested with the second-order confirmatory factor analysis. The goodness-of-fit indices of this tested construct were found to be adequate (TLI $=0.90, \mathrm{CFI}=0.92$, SRMR $=0.054$, RMSEA $=0.075$ ). The reliability analysis results reported by Shoshani (2018) in her study have revealed that the Cronbach alpha coefficients of the sub-dimensions vary between 0.74 and 0.92 . All these findings show that the adapted measurement tool is both valid and reliable.

In order to be able to conduct this scale adaptation study, Anat Shoshani was contacted via e-mail and the required permission was taken from her for the adaptation of the scale to Turkish. The measurement tool whose original form was written in English was translated to Turkish by three experts in the field of ELT individually. These translations were evaluated by two experts knowing English and the similarities and differences between them were detected. A high level of compliance was found between the translations. The cultural suitability of the measurement tool was evaluated together with two field experts and the required corrections were made on some items. In this way, the 96-item draft version of the scale was formed. Then, the back translation of the Turkish inventory was performed. The measurement tool was back translated to English by two experts with good command of English. The back-translated inventory was compared with its original form and its items were found to be in compliance with the items in the original inventory form. After the completion of the development process of the draft form, the required legal permissions were taken from the Burdur Ministry of National Education Directorate and from the administrations of the pre-school institutions where the study was planned to be conducted and then the application was started. The data of the current study were collected from the parents of 46 year olds attending state pre-school institutions in the spring term of the 2017-2018 school year. The data were collected from one parent per family. Of the 311 parents participating in the current study, $79.1 \%(\mathrm{n}=246)$ are females and $20.9 \%(n=65)$ are males.

The similarity of the construct of the adapted inventory with that of the original measurement tool was tested with confirmatory factor analysis. As the original scale has a specific factor structure, in the adaptation study, the use of only confirmatory factor analysis was considered to be enough. In order to determine the reliability of the scale, Cronbach alpha internal consistency coefficients and item total correlation values were examined. Confirmatory factor analysis was run in LISREL 8 and reliability analyses were conducted in SPSS 21 program package.

\section{FINDINGS, DISCUSSION AND RESULTS}

In order to reveal the construct conformity between the original form of the inventory and the adapted form, the first-order and second-order confirmatory factor analysis was conducted. The obtained first-order confirmatory factor analysis indices $\left(\mathrm{x}^{2} / \mathrm{sd}=2.32, \mathrm{NNFI}=0.93, \mathrm{CFI}=0.94, \mathrm{SRMR}=0.065, \mathrm{RMSEA}=0.065\right)$ and the secondorder confirmatory factor analysis indices $\left(\mathrm{x}^{2} / \mathrm{sd}=2.58, \mathrm{NNFI}=0.93, \mathrm{CFI}=0.93, \mathrm{SRMR}=0.076, \mathrm{RMSEA}=0.071\right)$ revealed that the model shows a good fit. The model fit indices of the original inventory were found to be similar to the model fit indices calculated in the current study. The findings obtained show that the adapted form of the Character Strengths Inventory for Early Childhood have 96 items, 24 factors and 4 main dimensions under which these factors are gathered, which are similar to the ones in the original scale. The 24 dimensions showing character strengths are as follows: Social intelligence, loving/being loved, kindness, fairness, teamwork, perspective, leadership, courage, love of learning, curiosity, appreciation of beauty, creativity, prudence, self-regulation, forgiveness, open-mindedness, modesty, persistence, zest, gratitude, spirituality, hope, humor, honesty. The four 
main dimensions explained by these character strengths together are intellectual, interpersonal, temperance and transcendence.

The results of the confirmatory factor analysis confirmed that the measurement tool has the construct validity. When the findings related to the reliability of the inventory were examined, it was found that the Cronbach alpha internal consistency coefficients found to be ranging from 0.74 to .0 .92 for the dimensions of the original measurement tool were calculated to be varying between .86 and 0.91 for the dimensions in the current study. These values show that the adapted measurement tool is reliable. Moreover, the corrected item total correlation of the inventory was calculated to determine the internal consistency of the scale and the differences between item means were found to be significant. According to validity and reliability analyses, it can be argued that the Character Strengths Inventory Early Childhood Form is a reliable and valid measurement tool that can be used to determine the character strengths of the children in their early childhood.

The Character Strengths Inventory Early Childhood Form (CSI-EC) shows the first expressions of the character strengths in the early childhood period and provides a tool easy to use for experts and researchers to evaluate the character strengths of the children in their early childhood period. Repetition of the reliability and validity studies of the inventory in different samplings will strengthen the reliability of the measurement tool. In the literature, correlations between character strengths and different variables have been investigated. Similarly, future research can determine some variables that can be related to the character strengths of the children living their early childhood period in the Turkish culture and then the relationships between them can be researched. Determination of children's character strengths can provide reliable data for researchers and guidance for parents, teachers and school counsellors to elicit children's character profiles. In addition, the character strengths are measurable and this will make contribution to consideration of children's characteristics while determining the services to be offered to them and make it easier to follow their development. 
Ek-1. Karakter Güçleri Envanteri Erken Çocukluk Formu (KGE-EÇ) örnek maddeleri

Değerli Anne,

$\mathrm{Bu}$ anket formunda çocuğunuzun karakter özellikleriyle ilgili bazı sorulara yer verilmiştir. Sizin de bu anketi doldurarak yürüttüğümüz bilimsel araştırmaya destek vermeniz bizim için çok değerlidir.

\begin{tabular}{|c|c|c|c|c|c|}
\hline ANKET ÖRNEK MADDELERİ & $\begin{array}{c}\text { Kesinlikle } \\
\text { Katılmiyorum }\end{array}$ & Katılmıyorum & $\begin{array}{l}\mathrm{Ne} \\
\text { Katllyorum } \\
\text { Ne } \\
\text { Katılmyorum }\end{array}$ & Katılıyorum & $\begin{array}{l}\text { Kesinlikle } \\
\text { Katıliyorum }\end{array}$ \\
\hline \multicolumn{6}{|l|}{$\begin{array}{l}\text { Çocuğunuz diğer çocuklarla oynarken uyumludur } \\
\text { ve neredeyse hiç münakaşa etmeden oynar. }\end{array}$} \\
\hline \multicolumn{6}{|l|}{$\begin{array}{l}\text { Çocuğunuz bilmediği } \begin{array}{c}\text { bir } \\
\text { konuşulduğunda, hemen } \\
\text { fazla bilgi edinmek ister. }\end{array} \\
\text { fanun }\end{array}$} \\
\hline \multicolumn{6}{|l|}{$\begin{array}{l}\text { Çocuğunuz çevresindeki kişilere fazlasıyla sıcaklık } \\
\text { ve sevgi gösterir. }\end{array}$} \\
\hline \multicolumn{6}{|l|}{ 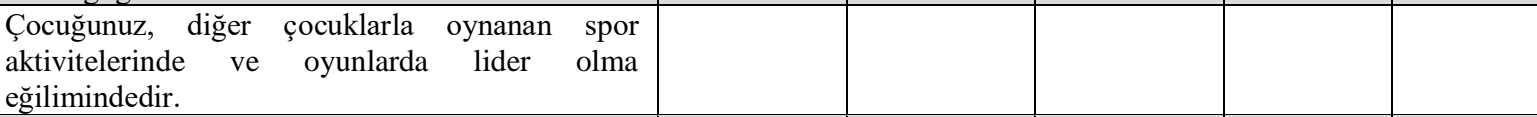 } \\
\hline \multicolumn{6}{|l|}{$\begin{array}{l}\text { Çocuğunuz arkadaş grubuyla oynarken diğer } \\
\text { çocukların görüşlerini dikkate alır ve buna sayg1 } \\
\text { gösterir. }\end{array}$} \\
\hline \multicolumn{6}{|l|}{$\begin{array}{l}\text { Çocuğunuz yumuşak bir mizaca sahiptir ve } \\
\text { genellikle öfkelenmez ve kontrolünü kaybetmez. }\end{array}$} \\
\hline \multicolumn{6}{|l|}{$\begin{array}{l}\text { Çocuğunuz etrafındaki dünyayı araştırmayı ve yeni } \\
\text { şeyleri keşfetmeyi sever. }\end{array}$} \\
\hline \multicolumn{6}{|l|}{$\begin{array}{l}\text { Çocuğunuz tüm çocuklarla (hoşlanmadığı çocuklar } \\
\text { dahil) adil bir ilişki kurar. }\end{array}$} \\
\hline \multicolumn{6}{|l|}{ Çocuğunuzun yalan söyleme eğilimi yoktur. } \\
\hline \multicolumn{6}{|l|}{$\begin{array}{l}\text { Çocuğunuz bir sorun yaşarsa etrafinda onu } \\
\text { dinleyecek biri olduğunu bilir. }\end{array}$} \\
\hline \multicolumn{6}{|l|}{$\begin{array}{l}\text { Çocuğunuz, kendisi için hazırlanan yemek ya da } \\
\text { aldığı bir hediye için teşekkür etmeyi ve bunları } \\
\text { nasıl takdir edeceğini bilir. }\end{array}$} \\
\hline $\begin{array}{l}\text { Çocuğunuz arkadaş grubuyla oynarken gruptaki } \\
\text { diğer cocukların istek ve ihtiyaçlarının farkındadır. }\end{array}$ & & & & & \\
\hline
\end{tabular}




\section{ETIK BEYANNAME}

$\mathrm{Bu}$ çalışmanın araştırma ve yazım sürecinde araştırmacılar tarafından bilimsel ve etik kurallara uyulduğunu, farklı eserlerden yararlanılması durumunda atıfta bulunulduğunu, kullanılan verilerde herhangi bir tahrifat yapılmadığını, araştırmanın tamamının veya bir kısmının farklı bir akademik yayın platformuna yayımlanmak üzere gönderilmediğini, belirtilen konularda araştırmanın yazarlarının bilgi sahibi olduğunu ve gerekli kurallara uyulduğunu beyan ederim. 26/02/2021

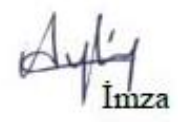

Aylin SOP

Araştırmanın Sorumlu Yazarı 